$\begin{array}{lll}\text { KULTURA } & \begin{array}{l}\text { POLSKA AKADEMIA NAUK } \\ \text { KOMITET SOCJOLOGII }\end{array} & \text { ISSN 0023-5172 } \\ \text { i } & \begin{array}{l}\text { INSTYTUT STUDIÓW POLITYCZNYCH } \\ \text { SPOLECLENSTWO }\end{array} & \\ 2010, \text { nr } 4 & \text { W STRONĘ PRZESZŁOŚCI }\end{array}$

MIROSEAW USTRZYCKI

Uniwersytet Jagiellonski

\title{
EDUKACJA DOMOWA I WYCHOWANIE W POLSKICH RODZINACH ZIEMIAŃSKICH NA LITWIE NA PRZEŁOMIE XIX I XX WIEKU
}

Zamierzam tu przedstawić działania wychowawcze i edukację domową prowadzoną w dworach jako mniej lub bardziej świadomy zamysł ukształtowania młodego pokolenia $\mathrm{w}$ imię pewnych wartości i norm środowiska, podejmowany $z$ naciskiem na preferowane wzorce osobowe oraz dla przyszłości dzieci zakorzenionej w przeszłości i tradycji, gdyż bez wątpienia taki był ziemiański ideał. Naturalnie, podobnie jak pod innymi względami, poszczególne siedziby ziemiańskie różniły się od siebie także w zakresie sposobów kształcenia potomstwa - w zależności od możliwości finansowych, odczuwanych potrzeb (często związanych z wykształceniem rodziców), czasu i chęci (lub ich braku), aby dołożyć starań w toku organizacji procesu edukacyjnego. Prezentowane ujęcie, tak skrótowe, z konieczności musi mieć charakter modelowy, odwoływać się do tendencji przeważających i najpowszechniej akceptowanych wzorców. Już na początku chcę jednak postawić tezę, że bardziej zróżnicowane były formy kształcenia niż stojące za nimi treści i cele, które chciano dzięki nim osiągnąć.

\section{OSOBY ODPOWIEDZIALNE ZA WYCHOWANIE I EDUKACJĘ DOMOWĄ}

Kresy, w tym Litwę, w interesującym nas okresie zaludniało mrowie guwernantek i korepetytorów, zarówno polskich, jak i cudzoziemskich, o niezmiernie zróżnicowanym stopniu wykształcenia i zdolnościach edukacyjnych. $Z$ reguły nie zatrudniano jednocześnie więcej niż trzy osoby (czasem zaś tylko jedna), dlatego nauczyciele musieli łączyć umiejętności z odległych nieraz od siebie zakresów. Jednak domowej edukacji i wychowania na przełomie wieków nie można utożsamiać tylko $\mathrm{z}$ pracą przyjezdnych. Ogromną rolę spełniali sami

Adres do korespondencji: mirou@poczta.onet.pl 
domownicy - rodzice, krewni, rezydenci - można powiedzieć: środowisko ziemiańskie jako całość, a zwłaszcza najbliżsi dziecka. Tym bardziej że rodzina — w odróżnieniu od często zmieniających się guwernantek - wywierała na dziecko wpływ przez bardzo długi czas i był to wpływ wszechstronny, pierwszorzędny zwłaszcza w zakresie wychowania ${ }^{1}$. Udzielanie życiowych wskazówek i karcenie za przewinienia, wspólne modlitwy czy wieczorne czytanie powieści, troska o obyczaje i moralność oraz opowieści o chwalebnej przeszłości rodu wszystko to niosło za sobą znaczący przekaz wychowawczy ${ }^{2}$. Coraz więcej wymagano pod tym względem zwłaszcza od matek ${ }^{3}$, od których przede wszystkim pochodził bagaż wartości, jaki otrzymywało potomstwo na całe dorosłe życie ${ }^{4}$. Ojciec w proces wychowawczy miał interweniować w ostateczności. Teoretycznie jego odpowiedzialność była wyższa w stosunku do synów zbliżających się do granicy dojrzałości. Nie wszyscy ojcowie mieli jednak na to czas. Nie tylko normy i wzorce środowiskowe pochodziły od najbliższych — nierzadko wśród domowników znajdowali się też chętni do nauczania bardziej książkowej wiedzy.

Wspomnieć trzeba jeszcze, że tradycyjnie dużą rolę w wychowaniu miały osoby miejscowe, ale spoza warstwy ziemiańskiej — mamki, piastunki, potem cała służba i folwarczne otoczenie. Działo się tak między innymi dlatego, że w dawnym modelu życia ziemiańskiego dla najmłodszych często zamknięty był świat dorosłych $z$ ich sfery, a kontakty $z$ rodzicami miały charakter skonwencjonalizowany i odświętny. $\mathrm{W}$ interesującym nas okresie nastąpiła już jednak bardzo znacząca zmiana w porównaniu choćby jeszcze z pierwszą połową XIX wieku. Dzieci, a tym bardziej młodzież, coraz więcej brały udziału w życiu rodzinnym i otaczano je coraz większą uwagą i troskliwością, w tym coraz sumienniej i systematycznej kształcono. Przejawy serdeczności i miłości wobec potomstwa stawały się jakby bardziej oczywi-

${ }^{1}$ M. Nawrot, Rola rodziny $w$ utrzymaniu tożsamości narodowej Polaków na terenie zaboru rosyjskiego $w$ drugiej potowie XIX i początkach wieku XX w świetle literatury wspomnieniowej i pamiętnikarskiej, „Acta Elbingensia", t. 1 (2003), s. 62; W. Korzeniowska, Edukacja i wychowanie różnych warstw społeczeństwa na ziemiach polskich — od drugiej połowy wieku XIX do roku 1918, Kraków 2004, s. 66.

2 W. Meysztowicz, Gawędy o czasach i ludziach, Londyn 1986, s. 19; J. Mineyko, Wspomnienia z lat dawnych, Warszawa 1997, s. 44. Warto porównać odnoszące się do ziem ukraińskich rozważania Tadeusza Epszteina na ten temat: „Po kolacji był czas na lekturę i wspólną zabawę. W wielu domach godziny wieczorne przeznaczano na kontakt i rozmowy dzieci z rodzicami i rodziną. Czas ten nie był stracony dla edukacji, gdyż starsi mogli wówczas przekazać swoim dzieciom treści, które nie znalazły się w programie lekcji”. T. Epsztein, Edukacja dzieci i młodzieży w polskich rodzinach ziemiańskich na Wotyniu, Podolu i Ukrainie w II potowie XIX wieku, Warszawa 1998, s. 44.

$3 \mathrm{O}$ roli kobiety w rodzinie ziemiańskiej na Kresach więcej w: M. Ustrzycki, Ziemianie polscy na Kresach 1864-1914. Świat wartości i postaw, Kraków 2006, s. 115-122.

4 Dbałość o trwanie wartości to główny wymóg środowiska ziemiańskiego wobec kobiety i podstawa jej oceny. Na przykład w nekrologu Marii z de Lippe-Lipskich Henrykowej hr. Zabiełłowej czytamy taką pochwałę: „Była to jedna z tych, coraz rzadziej spotykanych matron, która w odległym zakątku kraju stała na straży przechowywania tradycji i obyczajów prawdziwie chrześcijańskich i obywatelskich”. „Kraj” 1904, nr 12 z 19 marca (1 kwietnia), s. 23. 
ste, mniej się ich wstydzono nawet na salonach. Malało więc oddziaływanie służby czy folwarcznych rówieśników na rozwój ziemiańskich potomków (w odniesieniu do dziewczynek także wcześniej starano się wpływ ten ograniczać). Nie zmienia to faktu, że postać ukochanej niani wciąż pojawia się $\mathrm{w}$ wielu ziemiańskich pamiętnikach jako postać kluczowa dla najwcześniejszego dzieciństwa. Maria Czapska tak wspominała rolę swojej piastunki: „Nie umiała pisać, a czytała jedynie z książki do nabożeństwa, ale dała nam wszystkim, pod kierunkiem matki naszej, podstawy wychowania i dyscypliny, działając samą dobrocią, taktem i wrodzonym zmysłem pedagogicznym" 5 .

\section{FUNKCJA DWORU JAKO PRZESTRZENI EDUKACYJNO-WYCHOWAWCZEJ}

Kształcenie dzieci w domu było z jednej strony uświęconą tradycją, „naturalną" składową ziemiańskiego sposobu życia, z drugiej zaś — w szczególnych realiach doby popowstaniowej, o której traktuje ten tekst - koniecznościa, jeżeli chciało się, aby przekaz edukacyjny nie stał w sprzeczności z ziemiańskim systemem wartości. Edukacja i wychowanie przede wszystkim miały zagwarantować socjalizację dzieci z zachowaniem środowiskowych norm i wzorców zachowań oraz reprodukowanie ziemiańskiego modelu egzystencji wraz ze stojącymi za nim wartościami. Pomieszczenie działań edukacyjno-wychowawczych w przestrzeni domowej dawało najwięcej gwarancji powodzenia, powiązane też było $z$ wysoko wartościowanymi przez ziemian: rodzinnym trybem życia i lokalnością ${ }^{6}$. W przekonaniu ziemian dom miał w sposób naturalny promieniować cnotami, przywiązaniem do tradycji, w której oparcie znajdowały wszelkie wartości, być gwarantem prawidłowego wprowadzenia młodego człowieka w życie. Przynajmniej takie było oficjalne wyznanie kresowej, ziemiańskiej wiary. Do pozostawiania dzieci możliwie długo w zasięgu edukacji domowej skłaniały nie tylko preferencje, ale i lęk przed rosyjskim systemem szkolnym - rusyfikatorskim, a przy tym często destrukcyjnym wobec osobowości ucznia, bo raniącym jego uczucia. Aby przekazywać wartości młodemu pokoleniu, trzeba je było strzec przed taką edukacją. Oczywiście, w grę mógł wchodzić jeszcze jeden czynnik - nauka w domu mogła być tańsza, jeśli ograniczano się do angażowania w nią tylko domowników. Zatrudnienie paru guwernantek i/lub korepetytorów ten walor ekonomiczny już

\footnotetext{
${ }^{5}$ M. Czapska, Europa w rodzinie. Czas odmieniony, Kraków 2004, s. 175-176.

${ }^{6}$ Janina Żółtowska podkreśla w pamiętnikach, iż taka nauka pobierana od najbliższych i włączona w codzienny rytm dnia oznaczała, iż kulturą i wiedzą po prostu się „nasiąkało” bez przykrości kojarzonych z edukacją: „Mitologia, żywoty wielkich ludzi Plutarcha, krucjaty i kampanie Napoleona utkwiły na zawsze $\mathrm{w}$ mojej pamięci w połączeniu z pogodą dnia, [...] i jakimś drobnym szczegółem godziny spędzonej na ganku, albo na górze w bibliotece”. J. z Puttkamerów Żółtowska, Inne czasy — inni ludzie, Londyn 1959, s. 33-34.
} 
unieważniało. Dawało natomiast szansę (choć nie gwarancję) wyższej jakości nauczania ${ }^{7}$.

W dobie staropolskiej rozwinięciem kształcenia domowego było często przekazanie dziecka pod opiekę możniejszego rodu, na magnacki dwór. $\mathrm{Na}$ przełomie XIX i XX wieku tego typu możliwości były już jednak na Litwie skrajnie ograniczone. Względy praktyczne natomiast (wymagania pouwłaszczeniowej gospodarki i modernizującego się społeczeństwa) oraz wzrastające ambicje i zmieniające się standardy nakazywały kontynuowanie nauki na szczeblu gimnazjalnym i bardzo już często także wyższym, a tym samym wypuszczanie dzieci spod bezpośredniego rodzicielskiego nadzoru. W każdym razie dotyczyło to chłopców. W przypadku dziewcząt potrzeby takie wydawały się co najmniej nieoczywiste, a edukacja domowa najbardziej wskazana i w pełni wystarczająca. Wyjątków pojawiało się jednak coraz więcej. Nauczanie poza domem wiązało się już z ryzykiem odejścia młodego pokolenia od wzorców, które chcieli im przekazać starsi. Nie tylko zresztą system rusyfikatorski był tu wyzwaniem (można przecież było szukać wiedzy w Galicji czy w Europie Zachodniej), ale także nowe ideały i ideologie, które miało do zaproponowania gwałtownie zmieniające się społeczeństwo europejskie, a które były nader odległe od wzorców życia kresowego. Dlatego też to właśnie edukacja pozadomowa przyczyniała się do przeobrażeń ziemiańskiego wzorca kulturowego; kształcenie domowe zaś takie przemiany hamowało - taki był jeden $z$ jego kluczowych celów.

Sposobem na uniknięcie niebezpieczeństw, jakie niosło za sobą wypuszczenie dzieci w świat, mogło być swoiste przedłużanie domowej kurateli. Na Kresach w dobie zaborów rodzinna epistolografia kwitła na wielką skalę, była zwłaszcza namiętnością kobiet. Liczne listy przynosiły więc napomnienia, pouczenia i porady, tym samym podtrzymywały związek uczniów gimnazjów, a też uniwersytetów, z systemem domowego wychowania. Szczególnie usilnie przypominali rodzice swemu potomstwu o potrzebie wytrwania przy religii i zachowania reguł obyczajności. Metodą zagwarantowania, aby domowy przekaz wartości nie został zaprzepaszczony we wrogim mieście (ziemianie zawsze uważali, że wieś, to jest dwór, wyżej stoi pod względem moralnym ${ }^{8}$ ), były przenosiny matki do miasta na czas nauki dzieci i wspólne zamieszkanie. Działo się tak jednak tylko wyjątkowo z bardzo wielu powodów, spośród których już finansowe bywały wystarczające.

${ }^{7}$ A. Winiarz, Nauczanie domowe dzieci polskich $w$ dobie niewoli narodowej (1795-1918), w: Nauczanie domowe dzieci polskich od XVIII do XX wieku. Zbiór studiów, K. Jakubiak, A. Winiarz (red.), Bydgoszcz 2004, s. 112; K. Wróbel-Lipowa, Nauka domowa możnowładztwa i ziemiaństwa polskiego w XIX wieku, w: Nauczanie domowe dzieci polskich od XVIII do XX wieku, cyt. wyd., s. 152.

8 Inna sprawa, że dzieci nierzadko wywożono do miasta w karnawale, aby nabrały ogłady towarzyskiej. A. Bołdyrew, Matka i dziecko w rodzinie polskiej. Ewolucja modelu życia rodzinnego w latach 1795-1918, Warszawa 2008, s. 210. 


\section{ZAKRES DOMOWEJ EDUKACJI}

Wedle zasad środowiska ziemiańskiego w wyniku działań edukacyjnych i wychowawczych powinien zostać uformowany człowiek, który potrafi zająć w społeczeństwie miejsce należne mu z racji urodzenia i prestiżu jego warstwy społecznej. To była pierwsza przyczyna, dla której pewien poziom wykształcenia i ogłady towarzyskiej uznawano za niezbędny. We wcześniejszych dekadach XIX wieku, podobnie jak w epoce staropolskiej, obycie towarzyskie, podstawy etykiety i grzecznego zachowania mogły się jeszcze wydawać ziemianom wystarczającym celem edukacji. Na przełomie XIX i XX wieku jednak uznawano już, że posiadana wiedza i umiejętności powinny mieć systematyczny i w znacznej mierze (choć w żadnym razie nie wyłącznie) „książkowy” charakter. Dobrze tańczyć mazura - nie była to już wystarczająca wizytówka osoby z towarzystwa, choć jeszcze Hipolit Korwin-Milewski (ur. 1848) stwierdzał, iż prawie całe jego pokolenie uważało, że „wystarczają dobre maniery i elegancka powierzchowność, a wykształcenie jest tylko dla mieszczuchów lub szlagonów" 9 . Ponadto gospodarowanie w majątku, załatwianie interesów w mieście, kontakty $z$ kupcami i urzędnikami także wymagały już zdobycia adekwatnych kompetencji. Trzeźwo myślący ziemiańscy rodzice, choć często $z$ bólem, musieli brać pod uwagę również to, że przyszłe życie zawodowe potomstwa w ogóle może nie być związane $z$ rolą. A to już bez wątpienia stawiało przed rodziną poważniejsze zadania edukacyjne. Perspektywy te dotyczyły głównie chłopców - bez wątpienia nie mogli oni uniknąć wkroczenia $\mathrm{w}$ przyszłości $\mathrm{w}$ groźny świat poza rodzinnymi pieleszami.

Inaczej postrzegano przyszłe zadania dziewczynek — wkrótce żon i matek. Kształtując ich umiejętności, wychowywano je przede wszystkim na dobre gospodynie, kapłanki ogniska domowego, zapobiegliwe opiekunki męża i potomstwa, panie, które będą umiały zachować się w towarzystwie i wobec gości. Wszystkich natomiast, bez względu na płeć, przygotowywano do powielania ziemiańskich wzorców kulturowych i wartości, do dawania im świadectwa; w przypadku dziewczynek - do przekazywania ich nowym pokoleniom. Inaczej mówiąc, uczono, czym jest etyczne, dobre życie, jakie - i w jaki sposób - powinności wypełniać należy wobec „Boga i ludzi”. $Z$ tej perspektywy wybierano drogi edukacji: jej metody oraz treści, oraz kształtowano przekaz wychowawczy obarczony często dużym ładunkiem emocji. Jak więc widać, wiele starano się wpoić potomstwu i nie była to tylko wiedza podręcznikowa oraz zestaw zdrowasiek do odmawiania przed snem.

Listę przedmiotów, które wypełniały codzienne plany edukacji dzieci ziemiańskich, warto przedstawić choćby skrótowo. Zawsze szczególne miejsce zajmowały języki nowożytne. Język francuski od dawna był koroną ziemiańskiej

\footnotetext{
${ }^{9}$ H. Korwin-Milewski, Siedemdziesiąt lat wspomnień (1855-1925), Warszawa 1993, s. 13.
} 
edukacji (jako symbol wysokiej kultury, pozycji społecznej i dobrego smaku ${ }^{10}$ ), za nim szedł niemiecki; angielski bardziej był odpowiedni dla kobiet, choć jego ranga stale wzrastała. $Z$ reguły nie ograniczano się zresztą do nauki jednego języka; często również nie do dwóch. Przystępowały do niej dzieci kilkuletnie. Był to szczególny rys ówczesnego modelu edukacji domowej ${ }^{11}$. W planach zajęć dominowały przedmioty humanistyczne: po nauce czytania i pisania przychodził czas na naukę historii i powiązanej $z$ nią geografii oraz literatury ${ }^{12}$ (polskich przede wszystkim, choć nie sposób było wyobrazić sobie pominięcia wiedzy o starożytności). Coraz mocniej uświadamiano sobie rolę nauki historii jako części wychowania patriotycznego, zajmowała więc też coraz więcej miejsca $\mathrm{w}$ programach nauczania domowego. Języki starożytne wciąż były cenione, nie zajmowały jednak tak wysokiej pozycji, jak w zinstytucjonalizowanej edukacji tego czasu. Nieustannie kluczowa była nauka religii i katechizmu, rozpoczynana w bardzo młodym wieku. Rachunki znajdowały się nieodmiennie w zestawie przedmiotów, ale poza tym przedmioty ścisłe i przyrodnicze były słabo reprezentowane, choć dla biologii znajdowano coraz więcej uznania - przede wszystkim uczono jej pośród otaczającej dwór przyrody. Muzyka i umiejętność gry na instrumentach, taniec, rysunek dopełniały kanonu nauczania.

Najpierw - we wczesnym dzieciństwie - zdobywano umiejętności w zakresie czytania i pisania, języków, religii, rysunków, śpiewu. Na pozostałą część wiedzy (zwłaszcza w bardziej systematycznym wydaniu) przychodził czas $\mathrm{w}$ bardziej dojrzałym wieku. Występowały naturalnie pewne różnice między edukacją dziewcząt i chłopców. Te pierwsze więcej zdobywały umiejętności artystycznych, elementów ogłady towarzyskiej, a także niekiedy wiedzy humanistycznej. W edukacji chłopców poważniejsza była pozycja nauk ścisłych, języka rosyjskiego oraz kultury fizycznej. Ten podział nie był jednak ścisły, a w niektórych dworach brak było wręcz zróżnicowania przedmiotów ze względu na płeć. Interesująco na temat przypisania dziedzin wiedzy do płci - ale tym razem guwernantek, a nie uczennic (jedno $z$ drugim się jednak wiązało) - pisała Eliza Orzeszkowa: „[...] nauczycielce nie jest ściśle potrzebną znajomość

10 Wedle Janiny Żółtowskiej francuszczyzna była o wiele bardziej rozpowszechniona na Wołyniu niż na Litwie, czego jednym z powodów mogły być różnice w zamożności. Istotnie —im możniejszy dom, tym język francuski zdawał się bardziej niezbędny. J. z Puttkamerów Żółtowska, Inne czasy inni ludzie, cyt. wyd., s. 163.

${ }^{11} \mathrm{Na}$ ten temat Bolesław Prus: „Do tej pory wychowaniec od pieluch paplał po francusku lub po niemiecku przy pomocy osoby, którą znudziło pasanie kóz lub szorowanie rondli we własnym kraju. Tak edukowany nie wyuczył się ani francuskiego, ani polskiego języka, często zostawał idiota, co przypisywano dobremu urodzeniu, a co właściwie przychodziło stąd, że ów biedak nie miał po jakiemu myśleć, bałamucony kilkoma językami w tej epoce życia, w której jeden aż nadto wystarcza". B. Prus, Kroniki. Wybór, Warszawa 1987. Cyt. za: Źródła do dziejów nauczania domowego dzieci polskich w XIX $i$ początku XX wieku. Z bibliografia adnotowana pamiętników $i$ wyborem literatury pedagogicznej, K. Jakubiak i in. (red.), Bydgoszcz 2005, s. 180.

12 Z. z Tyszkiewiczów Klemensowa Potocka, Echa minionej epoki XIX-XX wiek. Moje wspomnienia, BN, rkps akc. 11711, t. I, k. 15-17. 
nauk przyrodniczych, dziejów matematyki; nauki te bowiem nie mają dotąd na targu umysłowości kobiecej ani żądania ani ofiary. Ale guwernantka [...] musi posiadać znajomość najmniej dwóch lub trzech języków obcych, być wirtuozką na fortepianie, mieć piękną manierę i doskonały akcent francuskiego mówienia" 13 .

W konstrukcji zestawu przedmiotów nauczanych w dworach dużo było tradycji, ale pojawiały się też elementy zmian. Właśnie ta ewolucja jest najciekawsza. Ostrożne na razie docenienie w niektórych rodzinach nauk fizycznych i przyrodniczych bywało już następstwem świadomości, że takiego wykształcenia wymaga nowoczesne społeczeństwo (coraz więcej młodych ziemian studiowało potem medycynę, nauki inżynieryjne czy architekturę). Inaczej miała się rzecz z historią czy literaturą polską. Przedmioty te nie były nowością, jednak ich znaczenie rosło. Warto zauważyć, że nie zdarzało się już niemal, by efektem edukacji była lepsza znajomość języka francuskiego niż polskiego (co $\mathrm{w}$ pierwszej połowie wieku XIX było nagminne, zwłaszcza w odniesieniu do kobiet). Wiązało się to ze wzrostem świadomości, iż konieczne jest systematyczne kształcenie o wymiarze patriotycznym — zwłaszcza $\mathrm{w}$ realiach polityki rusyfikatorskiej. Jednocześnie mocną pozycję w programach zdobywał sobie język rosyjski (dotyczyło to głównie nauki chłopców) - był on konieczny, jeśli decydowano się na dalszą edukację w kraju, a więc w szkołach rosyjskich, a poza tym był niezbędny w dorosłym życiu przyszłego właściciela majątku, który nie mógł funkcjonować bez kontaktu z rosyjskimi urzędnikami ${ }^{14}$.

Generalnie zestaw nauczanych przedmiotów w dużej mierze był wyrazem przekonania, że ukształtować należy człowieka z polorem, kulturalnego, $\mathrm{z}$ ogólną wiedzą o świecie - stąd przedmioty dające obycie $\mathrm{w}$ środowisku i wiedzę humanistyczną, znajomość polskiej i europejskiej kultury — w sumie: rodzaj ogłady cywilizacyjnej. Rosło znaczenie wymiaru praktycznego w doborze przedmiotów nauczania, ale jeszcze nie był on dominujący. Wydaje się przy tym, że ramy domowej edukacji wyznaczano z coraz większą skrupulatnością i świadomością celów, jakie chce się osiągnąć.

Przy wszystkich sformułowanych wcześniej zastrzeżeniach, że potrzeby edukacyjne daleko już wykraczały poza zdobycie odpowiednich manier i naukę etykiety, te elementy bagażu edukacyjnego wciąż były cenione. Nie mogło być inaczej w środowisku, które sąsiedzkie i rodzinne życie towarzyskie odczuwało jako najwyższą przyjemność. Umiejętności tańczenia i konwersacji oraz znajomość dobrych manier były ważne w życiu salonowym i niezbędne dla obu płci.

13 E. Orzeszkowa, Kilka stów o kobietach, Lwów 1873. Cyt. za: Źródta do dziejów nauczania domowego dzieci polskich w XIX i poczattu XX wieku, cyt. wyd., s. 114.

14 Kulturę rosyjską (nie tylko obyczaje, ale także na przykład literaturę) mało ceniono w większości dworów i zazwyczaj starano się uchronić dzieci przed jej wpływem. Łatwo też kształtowało się wśród najmłodszych poczucie wyższości wobec cywilizacji rosyjskiej. Zob. S. Kieniewicz, Jak być Polakiem pod zaborami, „Znak” 1987, nr 11-12, s. 39. 
Jak pisze Aneta Bołdyrew: „W kręgach arystokratycznych, ziemiańskich i burżuazyjnych dom rodzinny miał przygotować dziecko pod kątem kultury towarzyskiej do przyszłego życia społecznego i obyczajowego, w którym liczył się każdy gest" ${ }^{15}$. Chciałbym tu jednak zauważyć, że ziemianie litewscy (może poza najwyższą arystokracja) pozostawiali w swoim życiu towarzyskim dużo miejsca na pewną wiejską swobodę i pańską oryginalność. Innymi słowy, choć za niezwykle ważne uznawano zaznajomienie potomstwa $z$ formami życia towarzyskiego, to ich rygor zazwyczaj nie był przesadny. Umiejętności, które dziś określilibyśmy jako artystyczne czy sportowe, także traktowano wówczas raczej jako kompetencję do znalezienia się w dobrym towarzystwie. Rysunek, śpiew, umiejętność gry na instrumentach - a uczestniczono też $\mathrm{w}$ amatorskich przedstawieniach teatralnych, pisano wiersze - były spełnieniem tego wymogu zarówno w odniesieniu do chłopców, jak i dziewczynek, choć z wyraźnym wskazaniem na te drugie $^{16}$. Z kolei uzdolnień strzeleckich, pasji myśliwskiej i dobrej jazdy konnej oczekiwano głównie od chłopców. Otrzymanie pierwszego konia i pierwszej strzelby były to ważne etapy w osiąganiu dorosłości. O grze w karty nie myślano jako o cennym składniku wpajanych umiejętności, jednak kompetencje w tym zakresie nad podziw łatwo i powszechnie nabywano, aby je w dorosłym życiu - ku zgrozie moralistów — z namiętnością wykorzystywać. Wszystkie te umiejętności kształtowały się podczas sąsiedzkich czy rodzinnych zjazdów, do których okazją były imieniny, polowania, bale karnawałowe i wesela — to także były niezwykle ważne dla ziemiańskiego życia instytucje edukacyjne.

\section{PRZEKAZ WYCHOWAWCZY: PODSTAWOWE WZORCE I WARTOŚCI}

Wachlarz wartości, które chciano przekazać młodemu pokoleniu, był szeroki i w dworach dokładano wielu starań, aby uczynić to skutecznie. $Z$ jednej strony odwoływano się do treści i nakazów religijnych, patriotycznych, etycznych, czyniąc to $\mathrm{w}$ formie bezpośredniego przekazu opartego na pouczeniach, napomnieniach i przywoływaniu przykładów chwalebnych postaw przodków czy znamienitej przeszłości kraju. Wskazywano w ten sposób wyraźnie na właściwe wzorce, które należy podjąć. $Z$ drugiej strony umiejętność dobrego życia — zgodnego z wartościami środowiska i zasługującego na pochwałę - kształtowano przez wdrażanie do konkretnych zachowań, uznawanych za skuteczne w formowaniu należytego modelu osobowości. Na przykład poważania wobec najstarszych domowników uczono zlecając dzieciom wykonywanie wobec nich drobnych posług. Wymagano właściwych postaw wobec siebie samego i $\mathrm{w}$ relacjach $\mathrm{z}$ innymi. Jako wartości wpajane $\mathrm{w}$ ten sposób można wskazać

15 A. Bołdyrew, Matka i dziecko $w$ rodzinie polskiej. Ewolucja modelu życia rodzinnego w latach 1795 -1918 , cyt. wyd., s. 177.

16 Z. z Tyszkiewiczów Klemensowa Potocka, Echa minionej epoki XIX-XX wiek. Moje wspomnienia, BN, rkps akc. 11711, t. II, k. 2. 
przede wszystkim: szacunek dla starszych, poczucie obowiązku i odpowiedzialności, prawdomówność, samodyscyplinę, coraz częściej też szacunek dla pracy. Kłamstwo, nieposłuszeństwo, brak szacunku dla rodziców — to, co określano jako niewdzięczność — były to najpoważniejsze wykroczenia przeciw regułom, które starano się zaszczepić dzieciom ${ }^{17}$.

Niejednoznaczny był przekaz dotyczący kwestii hierarchii społecznej. Przede wszystkim różnie $z$ tym bywało $\mathrm{w}$ poszczególnych dworach, gdyż zarówno wśród członków rodzin, jak i pośród korepetytorów coraz więcej napotkać można było zwolenników „demokratycznych” — jak mówiono - czyli egalitarystycznych zasad życia społecznego; sporadycznie przenikały nawet $\mathrm{w}$ ten sposób do młodych umysłów idee socjalistyczne. Tymczasem jednak $\mathrm{w}$ środowisku ziemiańskim dominował społeczny konserwatyzm i szacunek dla hierarchii. $Z$ jednej strony ganiono zadzieranie nosa, a zwłaszcza pogardę dla drugiego człowieka, $z$ drugiej wpajano dzieciom przekonanie o przypisanej im szczególnej pozycji w społeczeństwie (co przynajmniej w teorii miało się wiązać nie tylko z przywilejami, ale i powinnościami) oraz starano się je do objęcia tej pozycji przygotować. Poczucie dumy budowano dość powszechnie na mitologizowanym często przekazie dotyczącym zasług przodków, wyjątkowości środowiskowego modelu kulturowego czy cywilizacyjnej misji ziemian w na pół barbarzyńskim otoczeniu. Wprawdzie hamowano niekiedy przejawy dziecięcego poczucia wyższości nad przedstawicielami niższych stanów, jednak nie należy sądzić, aby w każdym bez wyjątku dworze postawy takie były piętnowane. Tam zaś, gdzie je potępiano, niekoniecznie odnosiło to skutek, jeśli sami rodzice gorliwie zabiegali o zachowanie społecznych form podkreślających hierarchię, a potomstwu niejednokrotnie po prostu zabraniali bawić się z dziećmi służby jako nieodpowiednim dla nich towarzystwem, które może im wpoić zachowania niegodne ziemiańskiej sfery. Wspominany wcześniej — zachodzący od kilku dekad proces coraz większego zaangażowania ziemian w życie i wychowanie potomstwa (sto lat wcześniej to raczej służba dbała o ziemiańskich potomków) mógł wręcz pogłębiać zjawisko zamykania się dzieci we własnej grupie społecznej. Świat chłopskiej chaty był bez wątpienia bardzo odległy i niezrozumiały dla najmłodszych (a też dla całej warstwy ziemiańskiej), co nie sprzyjało empatii wobec „ludu" 18 .

Uznawano powszechnie, że miłość rodzicielska, jakkolwiek gorąca, winna być przy tym przede wszystkim mądra, a więc i surowa — takie też powinny być reguły wychowania. Pojawiały się nawet stwierdzenia, że na folgowanie sobie przyjdzie czas $\mathrm{w}$ dorosłym życiu, w latach dziecięcych zaś trzeba się na razie

17 A. Bołdyrew, Matka i dziecko $w$ rodzinie polskiej. Ewolucja modelu życia rodzinnego $w$ latach 1795 -1918, cyt. wyd., s. 171 i 176; W. Korzeniowska, Edukacja $i$ wychowanie różnych warstw społeczeństwa na ziemiach polskich — od drugiej potowy wieku XIX do roku 1918, cyt. wyd., s. 74.

18 A. Bołdyrew, Matka $i$ dziecko $w$ rodzinie polskiej. Ewolucja modelu życia rodzinnego $w$ latach 1795 -1918 , cyt. wyd., s. 173. 
do możliwych niedogodności tego życia hartować. Wielu sądziło, że mycie się $\mathrm{w}$ lodowatej wodzie i niesmaczne jedzenie mają zbawienny wpływ na uksztaltowanie młodej osobowości. Stanowisko takie było nader częste, częstsze jak sądzę - niż obrona beztroski dziecinnych lat. Dlatego też harmonogramy zajęć wychowanków - zwłaszcza gdy najęto kilku korepetytorów, bywały bardzo wypełnione. Inicjatywę własną $z$ reguły krępowało pełne podporządkowanie nauczycielom. System kar i nagród był w stałym użyciu, z naciskiem jednak na te pierwsze. Przy tym kary fizyczne uważano za konieczne i bardzo korzystne dla rozwoju, zwłaszcza etycznego, dziecka. Poza tym, że dobitnie wskazywały, co jest postępowaniem właściwym, a co niewłaściwym, wyrabiały nawyk posłuszeństwa i bezwarunkowego szacunku dla starszych oraz akceptacji hierarchiczności stosunków międzyludzkich (chyba że wywoływały bunt, choć takiej możliwości wychowawcy zdawali się nie dostrzegać). Niekoniecznie uczyły sprawiedliwości, gdyż wielu pamiętnikarzy i pamiętnikarek wskazuje, że arbitralność i niesłuszność kar była zjawiskiem niepokojąco częstym ${ }^{19}$. Jeśli panowały (bo przecież nie było to reguła) niekonsekwencja wymagań oraz zbytnia restrykcyjność $\mathrm{w}$ egzekwowaniu samoograniczania się dzieci i zachowywania przez nie „dobrych obyczajów”, często skutkowało to przyuczeniem dzieci do obłudy i wyrabiało nawyk stosowania drobnych oszustw wobec starszych. Był to bez wątpienia niezamierzony, ale nieuchronny efekt niektórych zabiegów wychowawczych.

Szukano też sposobów, aby wykształcić w młodym pokoleniu takie cechy jak gospodarność, samodzielność i oszczędność i aby poznało ono wagę obowiązkowości i własnej pracy, wartość pieniędzy. Zapewne nie wszędzie wartości te stawiano na pierwszym miejscu i uznawano za najwłaściwsze w życiu przedstawiciela społeczności ziemiańskiej (zwłaszcza materialistyczne podejście do życia uznawano za szczególnie naganne). Były to wartości rzeczywistości pouwłaszczeniowej, stopniowo wkraczającej w litewski ziemiański światek modernizującego się społeczeństwa i gospodarki opartej na prawach ekonomii wolnorynkowej. W omawianym okresie następował właśnie proces ścierania się dawnych ideałów życia ziemiańskiego - Rejem jeszcze pobrzmiewających i jego wiejską sielanką $-z$ tymi nowymi, „kapitalistycznymi”. I te drugie coraz częściej wygrywały. W praktyce dziecięcej edukacji zaś przejawiało się to na przykład w ten sposób, że coraz częściej najmłodsi uprawiali swój maleńki ogródek, a wyhodowane warzywa sprzedawali za kopiejki rodzicom. Drobne sumy dawano też zresztą dzieciom za oceny uzyskiwane u korepetytorów. Chłopcy jeździli z ojcem do prac rolnych, opiekowali się zwierzętami lub pomagali $\mathrm{w}$ układaniu umów z kupcami, dziewczynki zaś szyły sukienki bądź haftowały pościel, którymi można było później obdzielić okoliczną ubogą

19 A. Winiarz, Nauczanie domowe dzieci polskich $w$ dobie niewoli narodowej (1795-1918), cyt. wyd., s. 147-148; K. Kabacińska, Nauczyciel domowy — ideat a rzeczywistośc, w: Nauczanie domowe dzieci polskich od XVIII do XX wieku, cyt. wyd., s. 322-323. 
ludność, oraz uczyły się wydawania poleceń służbie czy kucharzowi. Tego typu prace dawały umiejętności, które mogły się przydać w dorosłym życiu, a ponadto były nauką „bycia pożytecznym”, wykonywania swych obowiązków wobec społeczności, przygotowywały do ról społecznych: gospodarza majątku, gospodyni domu ${ }^{20}$.

Dużą wagę przywiązywano do wyrabiania nawyków dbania o siebie o schludność ubioru i czystość, którą wiązano też z czystością moralną. Szanować siebie znaczyło także nie mówić o rzeczach nieprzystojnych i nieprzyzwoitych. Wiele o tym sposobie kształtowania młodych umysłów mógłby powiedzieć Zygmunt Freud. Ta sfera edukacji była oparta w dużej mierze na przemilczeniu - zakrywała to, co mogło kojarzyć się z cielesnością i seksualnością. Wiedza w tym zakresie była teoretycznie (czasem czyniono sporo starań, aby i praktycznie) niedostępna dla dzieci i dorastającej młodzieży. W przypadku dziewczynek każde zainteresowanie tą sferą było niedopuszczalne, w przypadku chłopców w każdym razie niewskazane ${ }^{21}$. Oczywiście na edukację seksualną nie było miejsca, sporadycznie raczej zdarzało się przekazywanie podstawowych wiadomości pozwalających zrozumieć własną cielesność. Zapewne rygory te bywały rozluźniane w odniesieniu do chłopców - do jakiego stopnia nie sposób, ze względu na powściągliwość źródeł ${ }^{22}$, rozstrzygnąć. Wiedzę o seksualności zastępowały liczne przestrogi przed zejściem na złą drogę, często niezrozumiałe dla przestrzeganych, gdy nie wolno było wskazać wyraźnie, o czym mowa. Do rangi anegdotycznych urosły zabiegi o ograniczanie w otoczeniu dworu obecności zwierząt do jednej płci, aby dzieci nie stały się świadkami niestosownej sceny, czy dorysowywanie w podręcznikach sztuki starożytnej bielizny reprodukcjom posąó́w ${ }^{23}$. W wielu dworach również doboru lektur, z którymi miały zapoznać się dzieci, dokonywano pod kątem obyczajności i moralnej nieskazitelności, a kryteria ocen były surowe.

20 A. Bołdyrew, Matka i dziecko $w$ rodzinie polskiej. Ewolucja modelu życia rodzinnego $w$ latach 1795-1918, cyt. wyd., s. 174-177; W. Korzeniowska, Edukacja $i$ wychowanie różnych warstw społeczeństwa na ziemiach polskich — od drugiej połowy wieku XIX do roku 1918, cyt. wyd., s. 64, 79-80. Helena Stankiewiczowa tak wspominała edukację swojego brata Tomasza: „Babunia Antosia przygotowywała Tomasza na przyszłego dziedzica rodzinnych dóbr. Chociaż był małym chłopcem, siedział przy niej, kiedy rozliczała się z zarządcami, jeździł z nią po polach, doglądał wyrębu lasu. Czasami dochodziło do absurdalnych sytuacji. Miał chyba 10 lat, gdy babunia Antosia kazała mu zdecydować, kiedy zarządca ma skosić koniczynę. I chociaż jeszcze było za wcześnie, została skoszona, bo tak zarządził mój brat”. W. Wiśniewski, Pani na Berzenikach. Rozmowy z Helena z Zanów Stankiewiczowa, Warszawa 2003, s. 25.

${ }^{21}$ A. Bołdyrew, Matka i dziecko $w$ rodzinie polskiej. Ewolucja modelu życia rodzinnego $w$ latach 1795-1918 , cyt. wyd., s. 144-150 i 175.

22 Z brakiem zahamowań można się spotkać jedynie sporadycznie. Najbardziej skłonny do podawania nieobyczajnych informacji wydaje się Melchior Wańkowicz w Szczenięcych latach. Sporo pikantnych szczegółów podaje też Wacław Lednicki: Pamiętniki, t. 1, Londyn 1963.

${ }^{23}$ Obszernie na ten temat: M. Czapska, Europa $w$ rodzinie. Czas odmieniony, cyt. wyd., s. 199-203. 


\section{PRZEKAZ WYCHOWAWCZY. TRIADA: RELIGIA-TRADYCJA-PATRIOTYZM}

Nauki moralne były osadzone w przekazie religijnym, który stanowił kluczową i niezbędną część wychowania. Religia była cenna jako część tradycji, jako element polskości - słowem jako dziedzictwo środowiska oraz, samoistnie, jako drogocenna prawda, gwarantująca przestrzeganie norm etycznych i trwanie ładu opartego o wartości. Która $z$ tych funkcji stała na pierwszym miejscu — trudno wyrokować, tak bardzo się ze sobą splotły. Oczywiście w deklaracjach na pierwszy plan wysuwano głęboką wiarę w Opatrzność Bożą, a wychowanie dziecka bez odwołania się do niej było trudne do wyobrażenia. Religia miała być dla wychowania fundamentem. Wiara religijna stanowiła zaś tę prawdę, której przekazanie uważano za wymóg etyczny, ponieważ wprowadzała kolejne pokolenia na właściwą drogę życia, pozwalała przetrwać $\mathrm{w}$ tych pokoleniach temu, co miano za najcenniejsze w obrębie ziemiańskiego (i polskiego) wzorca kulturowego. Wychowanie religijne było rolą przede wszystkim matki i była to jej wielka odpowiedzialność, a powodzenie stanowiło przedmiot chluby w środowisku ziemiańskim.

Niezwykle trudno dać odpowiedź na pytanie: jak głęboki był ten przekaz religijny? Bez wątpienia najpowszechniej i najbardziej konsekwentnie dbano o wytworzenie u potomstwa nawyku przestrzegania form i obrzędów. Poranne i wieczorne modlitwy (te ostatnie często w szerokim rodzinnym gronie), nabożeństwa (nie zawsze możliwe było uczestniczenie w odprawianych w kościele, ale wnętrze dworu także stanowiło dla nich odpowiednie miejsce), pamięciowe przyswajanie przez dzieci katechizmu oraz opowieści o losach świętych i męczenników, wybrane historie biblijne, kult obrazów świętych - te elementy dominowały ${ }^{24}$. Kluczowy, jak w całym polskim katolicyzmie tego czasu, był kult maryjny. Trudno oczywiście oczekiwać ambitnej, bogatej w treści teologiczne edukacji w odniesieniu do kilkulatków. Wraz z dorastaniem wychowanków poszerzano zakres opartego na wierze przekazu etycznego. Nieodmiennie ważkim wydarzeniem w życiu dzieci była spowiedź - część systemu surowej sprawiedliwości, jaka miała, przynajmniej w założeniu, przyświecać działaniom wychowawczym. Była to też okazja do wysłuchania napomnień ugruntowanych w religii od osoby najbardziej kompetentnej — kapłana. Duchowni, których bardzo chętnie goszczono, nie byli jednak szczególnie angażowani w proces wychowawczy, ich obecność we dworach z reguły miała charakter towarzyski. Bez wątpienia problemem był ponadto niedobór księży będący skutkiem zwróconej przeciw Kościołowi katolickiemu represyjnej polityki rosyjskiej. Wykładnia i rozumienie prawd wiary i bardziej złożonych kwestii teologicznych w konsekwencji pozostawiały sporo do życzenia ${ }^{25}$.

24 Tamże, s. 153-154, 193-194.

25 A. Bołdyrew, Matka i dziecko $w$ rodzinie polskiej. Ewolucja modelu życia rodzinnego $w$ latach 1795 -1918, cyt. wyd., s. 163-170; A. Szarkowska, Rola wychowania religijnego w nauczaniu domowym 
Działo się tak nie tylko dlatego, że nikt nie był do takiej edukacji dostatecznie przygotowany: ani rodzice, ani korepetytorzy, ani w konsekwencji uczniowie. Paradoksalnie, w równiej mierze przyczyną był fakt, że środowisko ziemiańskie traktowało religię jako coś bardzo bliskiego i w pewnym sensie naturalnego - nie wymagającego zatem roztrząsań. Przywiązanie do wiary kształtowano szczególnie chętnie przez odwoływanie się do emocji i kreowanie relacji z osobami świętymi w bardzo osobisty sposób. Dzieci przestrzegano przed tym, aby ich czyny nie zasmucały Matki Boskiej, aby nie obrażały Chrystusa, którzy nieustannie wraz z aniołami mieli baczyć na postępki najmłodszych. Janina Żółtowska pisała: „Stosunek do religii był emocjonalny. Trzymano się jej raczej $z$ tradycji i obyczaju, niżeli znano jej nakazy" ${ }^{26}$. Religia i tradycyjne formy jej wyrazu bez wątpienia stanowiły bardzo ważny element tożsamości środowiska. Pozwolenie na to, by dziecko od nich odeszło, było porażką procesu socjalizacji i przekazywania wartości (podobnie było z patriotyzmem i przywiązaniem do tradycji przeszłych pokoleń). Stąd wielka troska o wytworzenie w wychowankach głębokiego przywiązania do tych wartości.

Chęć kształtowania szacunku, miłości i przywiązania do tego, co stanowiło dziedzictwo wspólnoty ziemiańskiej, określała treści i narzędzia edukacji i wychowania patriotycznego. Dokonywało się ono poprzez przekaz pamięci rodzinnej z jednej strony, a wiedzy o przeszłości (chwale i martyrologii) narodu $z$ drugiej. Wymiar prywatny — rodzinny — jak się wydaje, dominował przy tym. Warto raz jeszcze oddać głos Janinie Żółtowskiej, tym razem nie jako dojrzałej pamiętnikarce, ale jako szesnastoletniej autorce dziennika: „Co mnie obchodzi przyszłość, zakryta czarnym woalem i niepewna? Co mnie obchodzi teraźniejszość pełna często smutków choć też radosna. Oczy mam zwrócone do przeszłości dalekiej, do minionych lat, do tego co stworzyło nas i nasze myśli. Są to ruiny, ale żyjące w nas samych, bo nas stworzyły. Nie trzeba się od tego odwracać. Bo to jest naszą iskrą i naszym duchem" 27. Tożsamość ziemiańska w dużej mierze kształtowała się jako tożsamość spadkobierców sławy przeszłych pokoleń. W edukacji i wychowaniu odwoływano się do dumy, jaka mogła rodzić się w wychowankach dzięki poznaniu czynów przodków i przeszłości rodu, majątku, najbliższej okolicy. Jednocześnie coraz więcej miejsca poświęcano edukacji historycznej związanej z najważniejszymi (najchwalebniejszymi) momentami dziejów Rzeczypospolitej Obojga Narodów bądź z martyrologią narodu. Zaznajamiano dzieci zarówno $z$ popularnymi syntezami historycznymi ${ }^{28}$, jak

dzieci w okresie zaborów, w: Nauczanie domowe dzieci polskich od XVIII do XX wieku, cyt. wyd., s. 229-236 .

26 J. z Puttkamerów Żółtowska, Inne czasy — inni ludzie, cyt. wyd., s. 87.

27 J. z Puttkamerów Żółtowska, Dzienniki, BN, rkps 10277, t. I, k. 2.

28 W kanonie podręczników znajdowały się: Dzieje Polski $w 24$ obrazach Władysława Ludwika Anczyca, Śpiewy historyczne Juliana Ursyna Niemcewicza, Pielgrzym w Dobromilu Izabeli z Flemingów Czartoryskiej; rzadziej w użyciu były prace Joachima Lelewela, a z nowości Michała Bobrzyńskiego. 
i z literaturą piękną - w obu wypadkach skupiano się na tych elementach narracji historycznej, które niosły duży ładunek emocji patriotycznych. Nieocenioną w budzeniu tych uczuć była poezja romantyczna, później także twórczość Henryka Sienkiewicza, którego powodzenie na Kresach było ogromne ${ }^{29}$.

Owe dwie składowe wychowania patriotycznego (pamięć rodowa i historia narodu) wyodrębniam tu tylko dla jasności wywodu. Trzeba bowiem wyraźnie powiedzieć, że były ze sobą mocno splecione. Portrety zasłużonych lub godnych pamięci ze względu na swe przymioty przodków sąsiadowały z wyobrażeniami króla Jana Sobieskiego, Rejtana, Kościuszki, księcia Poniatowskiego. Pamiątki po sprawujących urzędy czy walczących w polskim wojsku dziadach nadawały głębszy sens książkowej wiedzy o historii. I dlatego choć korzystano $z$ wielu podręczników, domowe pamiątki oraz rodzinne opowieści najskuteczniej umacniały przekaz patriotyczny, który wywodzono $z$ nauki przeszłości. Jak pisał Bohdan Cywiński: „Dwór był symbolem wielu wartości - oczywiście dwór idealny, wzorcowy, sielankowy i patetyczny zarazem. Był symbolem trwania. Był symbolem polskości [...]. Przodkowie z niewydarzonych portretów poubierani byli w kontusze lub mundury dawnych wojsk polskich, tu i ówdzie znajdowały się resztki ich oręża, czasem ryngraf lub chociażby sygnet herbowy" 30 . Rolę odgrywały drobiazgi zachowane po przodkach, meble, bron, a nawet trofea myśliwskie. Często praktykowanym obyczajem było śpiewanie pieśni patriotycznych i deklamowanie romantycznej poezji, organizowanie przedstawień teatralnych i żywych obrazów, które wielokroć odwoływały się do świetnej, przedrozbiorowej przeszłości kraju. Tak jak to ilustruje cytowany wyżej zapisek Janiny Żółtowskiej, dzieci mogły dzięki temu zyskać poczucie uczestnictwa w ciągłości pewnej tradycji ${ }^{31}$.

Źródłem wielkich emocji bywało zwłaszcza odwołanie do martyrologii narodu, a niejeden spośród mieszkańców dworu poczytywał sobie przy tym za obowiązek rozmawiać z najmłodszymi wprost o aktualnej sytuacji kraju. Stanisław Mianowski wspominał spacery z babką, gdy był kilkulatkiem: „Rozmawialiśmy na najrozmaitsze tematy: religijne, o tym, że jestem Polakiem

${ }^{29}$ J. Mineyko, Wspomnienia z lat dawnych, cyt. wyd., s. 49; J. z Puttkamerów Żółtowska, Inne czasy — inni ludzie, cyt. wyd., s. 71.

30 B. Cywiński, Rodowody niepokornych, Paris 1985, s. 211. Por. S. Mianowski, Wspomnienia 1895-1945 , BN, rkps akc. 15277, z. 2, k. 7.

31 W. Wiśniewski, Ostatni z rodu. Rozmowy z Tomaszem Zanem, Warszawa-Paryż 1989, s. 33; G. Kozłowska, M. Nawrot, Metody nauczania domowego $w$ rodzinie polskiej w zaborze rosyjskim $w$ XIX i na początku XX wieku, „Acta Elbingensia”, t. 2 (2004), s. 123-124; A. Bołdyrew, Matka i dziecko w rodzinie polskiej. Ewolucja modelu życia rodzinnego w latach 1795-1918, cyt. wyd., s. 188; B. Cywiński, Rodowody niepokornych, cyt. wyd., s. 221-222; E. Kowecka, W salonie $i$ w kuchni. Opowieść o kulturze materialnej pałaców $i$ dworów polskich w XIX w., Warszawa 1989, s. 67; B. Jedynak, Obyczaje domu polskiego w czasach niewoli 1795-1918, Lublin 1996, s. 7; A. Myśliwska, Między tradycja a wspótczesnościa. Wizerunek dworu szlacheckiego w twórczości Józefa Weyssenhoffa, w: Dworki, pejzaże, konie, K. Stępnik (red.), Lublin 2002, s. 114; T. Epsztein, Edukacja dzieci i młodzieży w polskich rodzinach ziemiańskich na Wotyniu, Podolu i Ukrainie w II potowie XIX wieku, cyt. wyd., s. 38. 
i co to znaczy, o Polsce i o tym, że jest ona pod obcym panowaniem, w szczególności dotyczy to i Solecznik..."32. Tego typu przekaz mógł jednak nieść za sobą ryzyko zbytniego patriotycznego roznamiętnienia wychowanków, a tego często unikano - społeczność ziemiańska na Kresach na przełomie XIX i XX wieku już dawno stłumiła w sobie tendencje buntownicze.

W tym kontekście ważną (ale i niezwykle kontrowersyjną) kwestią w obrębie przekazu skierowanego do młodego pokolenia był zwłaszcza problem prezentacji i oceny powstania styczniowego. A pierwsze pytanie, na które trzeba było sobie odpowiedzieć, brzmiało: czy w ogóle wiedzę o nim udostępniać potomkom, jak ją naświetlić, jakie to może przynieść skutki? Pamięć o powstaniu była bowiem $\mathrm{w}$ środowisku ziemiańskim nacechowana ambiwalencją (czarna jego legenda raczej dominowała) ${ }^{33}$. Przede wszystkim zaś lękano się podjęcia przez młodych idei - romantycznej i straceńczej przy tym - walki zbrojnej o wolność ${ }^{4}$. Dlatego też w wielu dworach zachowywano daleko idącą ostrożność i powstrzymywano się przed uwzględnianiem relacji o styczniowym zrywie jako ważnego elementu edukacji. Bywało jednak różnie: $w$ jednych dworach pamięć powstania pokrywało milczenie, $w$ innych wpisywano je $w$ świadomość dzieci od najmłodszych lat.

Trzeba zauważyć, że przełom XIX i XX wieku na Litwie to czas, kiedy pamięć o powstaniu w dużej mierze ulegała odtabuizowaniu, z coraz mniejszą gorliwością określano je jako szaleństwo. W dwadzieścia lat po powstaniu zaczęto mówić o nim w sposób bardziej wyważony i strach przed podjęciem na nowo przez młodych katastrofalnej drogi malał. Warto przypomnieć, jak wiele miejsca zajmuje kwestia pamięci o powstaniu w Nad Niemnem Elizy Orzeszkowej - powieści, która tak dobrze oddaje dylematy ziemian litewskich u schyłku XIX wieku. Powstanie coraz częściej wspominano nie tylko jako przestrogę, ale i jako pozytywnie nacechowaną cząstkę dziedzictwa. Pozostawało bowiem bez wątpienia jednym $z$ najważniejszych elementów pamięci zbiorowej wspólnoty ziemiańskiej i jako takie nie mogło nie powracać również w przekazie skierowanym do młodego pokolenia. Przy tym należy pamiętać, że ów przekaz, płynący od poszczególnych domowników czy sąsiadów, mógł być bardzo zróżnicowany (różne prezentowano postawy wobec powstania w czasie jego trwania i różnie później własne czyny oceniano; w litewskich dworach nie brakowało przy tym powstańczych weteranów, wielu stopniowo wracało ze zsyłek). Czasem jedna osoba przesiąknięta wiarą $\mathrm{w}$ wagę powstańczej martyrologii mogła wzbudzić w młodych słuchaczach gorące uczucia, których może nie życzyliby sobie ich

32 S. Mianowski, Wspomnienia 1895-1945, BN, rkps akc. 15277, z. 1, k. 2.

${ }^{33} \mathrm{Na}$ temat złożonego problemu stosunku ziemian Kresów do powstania styczniowego więcej w: M. Ustrzycki, Ziemianie polscy na Kresach 1864-1914. Świat wartości i postaw, cyt. wyd., s. 359-361.

34 R. Jurkowski, Ziemiaństwo polskie Kresów Pótnocno-Wschodnich 1864-1904. Działalność społeczno-gospodarcza, Warszawa 2001, s. 76. 
rodzice ${ }^{35}$. Ewolucja sposobu postrzegania powstania styczniowego powodowała, że właśnie pokolenie dorastające na przełomie wieków, w odróżnieniu od tego urodzonego wkrótce po powstaniu, aktualizowało w swej świadomości (a później i w działaniach) tradycję walki o wartości narodowe ${ }^{36}$.

Dom rodzinny miał zapewnić wytworzenie u dzieci przywiązania do zespołu wartości skupionych wokół pojęć ojczyzny, wiary, tradycji, moralności ${ }^{37}$. Wartości te traktowano jako nierozerwalnie związane i dopiero wszystkie razem stanowiły o treści patriotyzmu, który nie był traktowany wyłącznie jako miłość do abstrakcyjnie pojętej wspólnoty narodowej; był raczej pewnym obliczem swojskości - nacechowanej emocjonalnie i etycznie. Tak rozumiana polskość zawierała w sobie przywiązanie do mniejszej, ale i bliższej ojczyzny litewskiej. Na rozwój emocji patriotycznych wpływ miało chociażby umiłowanie piękna otaczającego krajobrazu, sąsiadujących dworów i obyczajów zamieszkujących je osób, z którymi tak często się stykano. Na wartości te także zwracano uwagę w procesie wychowawczym, wrażliwość na nie starano się kształtować. W ten sposób od najmłodszych lat dzieci wrastały w kraj i w ziemiańskie towarzystwo, uznając je za swoje naturalne środowisko i otaczając miłością należną „krajowi lat dziecinnych". Patriotyzm oznaczał w konsekwencji przede wszystkim miłość do tego, co rodzime, do wartości wspólnoty, i był dla ziemian litewskich w jakiejś mierze tożsamy z ideałem dobrego, uczciwego życia.

$\mathrm{W}$ omawianych działaniach edukacyjnych i wychowawczych - zwłaszcza $\mathrm{w}$ ich religijnym i patriotycznym wymiarze - bardzo silnie zaznaczała się potrzeba skonsolidowania środowiska $\mathrm{w}$ obronie jego wartości i pozycji, dla których zagrożenie widziano głównie $\mathrm{w}$ dyskryminujących i rusyfikatorskich działaniach władz rosyjskich. Dwór stawał się dla tych wartości ostoją, przy-

35 W. Wiśniewski, Ostatni z rodu. Rozmowy z Tomaszem Zanem, cyt. wyd., s. 30; S. Mianowski, Wspomnienia 1895-1945, BN, rkps akc. 15277, z. 1, k. 9-10; M. Jałowiecki, Na skraju imperium, wybór i układ tekstu Michał Jałowiecki, Warszawa 2000, s. 17-18; M. Wańkowicz, Szczenięce lata, Warszawa 1934, s. 86-91.

$36 \mathrm{~W}$ odniesieniu do Ukrainy artykuł tej kwestii poświęcił Tadeusz Epsztein: Tradycja powstań narodowych $w$ wychowywaniu młodego pokolenia ziemian polskich na Wotyniu, Podolu $i$ Ukrainie $w$ drugiej połowie XIX wieku, „Mazowieckie Studia Humanistyczne” 1998, nr 2.

37 Taki dom polski - mitologizując go w romantycznej manierze - ma na myśli Barbara Jedynak, gdy pisze, iż dom czasów niewoli „[...] pozwolił przetrwać, schronić pamiątki narodowe, wychować dzieci na Polaków, zapewniał elementarną egzystencję. Dzięki domowi polskiemu zachowały się obyczaje, język, religia ojców. Mimo tragicznych losów miał siłę tworzenia nowych wartości w kulturze, był gniazdem, z którego stale na nowo zrywały się do lotu coraz to nowe, kolejne pokolenia, zawsze walczące o to samo - o wolność. W świadomości społecznej dom był nierozerwalnie wiązany z rodziną, narodem, ojczyzną i wolnością". B. Jedynak, Obyczaje domu polskiego w czasach niewoli 1795-1918, cyt. wyd., s. 5. Oczywiście taki modelowy dom nigdzie nie istniał, był jednak wzorcem, pod którym patriotyzm polski - także kresowy — chętnie się podpisywał, z zastrzeżeniem może jedynie znacznej ostrożności co do owej walki o wolność. Por. też: M. Nawrot, Rola rodziny $w$ utrzymaniu tożsamości narodowej Polaków na terenie zaboru rosyjskiego $w$ drugiej połowie XIX i początkach wieku XX w świetle literatury wspomnieniowej i pamiętnikarskiej, cyt. wyd., s. 52 i 66; A. Mencwel, Przedwiośnie czy potop. Studium postaw polskich w XX wieku, Warszawa 1997, s. 16. 
szłe pokolenia nadzieją na ich przetrwanie. Na uczestnikach procesu edukacyjnego spoczywał więc patriotyczny (odnoszący się do patriotyzmu w takim kształcie, jaki tu zarysowałem) obowiązek, przy czym przede wszystkim był on przypisywany matce. W konsekwencji wytworzył się i stale umacniał model Matki-Polki, odpowiedzialnej za przyszłość narodu uosobioną w jej dzieciach oraz za przekaz wartości w duchu katolickim i raczej konserwatywnym. Rola kobiety-matki wzrastała, a oznaczało to, że i od niej wymagano większego wykształcenia. Dziewczynki wprawdzie wciąż kształcone były na gospodynie i dobre żony, ale coraz więcej przekazywano im tej wiedzy z zakresu polskiej historii, kultury, literatury i geografii oraz nieodmiennie religii, która miała zagwarantować ich kompetencję $\mathrm{w}$ zakresie wychowania patriotycznego potomstwa. Ta funkcja kobiety - przekazicielki wartości narodowych — była postrzegana jako niezwykle istotna, przyszła matka musiała więc być do niej odpowiednio przyuczona ${ }^{38}$. $Z$ emfazą o zasługach kobiet pisał w swoich wspomnieniach na przykład Julian Talko-Hryncewicz: „O ten hart ducha naszych matek, sióstr, żon i córek rozbijały się najskrajniejsze tendencje rusyfikatorskie. [...] Jeżeli nie ulegliśmy $\mathrm{w}$ tej ciężkiej, nierównej walce $z$ podstępnym wrogiem prawie przez półtora wieku, szczególnie na Litwie - jeżeli ochroniliśmy choć w części nasze znicze domowe, zawdzięczamy to w znacznej mierze niewiastom. O cześć Wam, niewiasty nasze!" 39.

\section{PODSUMOWANIE}

Na przełomie XIX i XX wieku wciąż w znacznej mierze trwał na Litwie stary świat wartości i norm wywiedzionych z czasów dawnej świetności społeczności ziemiańskiej. Wspólnota chciała te wartości ocalić i przekazać w przyszłość. Jej wychowankowie trafiali jednak już coraz częściej po etapie edukacji domowej do szkól, w których mogli (niekoniecznie w ramach oficjalnych zajęć) stykać się $z$ wielością idei nowych. Wkrótce zaś mieli wkroczyć w czas wojny i rewolucji i znaleźć się w nowej, zrodzonej przez nie rzeczywistości. Ci, którzy przebyli tę szkołę gwałtownych zmian społecznych, z trudem tylko mogli znaleźć drogę powrotu do litewskiego matecznika, w którym wiek XIX przeplatał się jeszcze z wcześniejszymi stuleciami doby staropolskiej. Świat ten został ziemianom odebrany. Iluż wychowanków ziemiańskich dworów, dokonując wyborów życiowych w niepodległej już Polsce, musiało iść na kompromis z realiami

38 A. Bołdyrew, Matka i dziecko $w$ rodzinie polskiej. Ewolucja modelu życia rodzinnego w latach 1795 -1918 , cyt. wyd., s. 177-180, 187.

39 J. Talko-Hryncewicz, Z przeżytych dni (1850-1908), Warszawa 1930, t. 1, s. 51-52. Por.: S. Siekierski, Kultura szlachty polskiej w latach 1864-2001, Pułtusk 2003, s. 179-180. Takimi strażniczkami narodowych tradycji są też bohaterki literackie - na przykład u Marii Rodziewiczówny; zob. A. Martuszewska, Jak szumi Dewajtis? Studia o powieściach Marii Rodziewiczówny, Kraków 1989, s. $163-164$. 
bardziej egalitarnej rzeczywistości społecznej, dawne wartości traktując jako przeżytek? Iluż wśród nich ukształtowało się w konsekwencji na socjalistów i polskich nacjonalistów, a nawet szczerych Litwinów (w nowoczesnym znaczeniu)? Oczywiście, były i żubry litewskie - ale wcale nie dominowały. Iluż wybrało oportunizm i karierę o materialistycznym wymiarze? To znaczy, że wysiłek edukacji domowej nie w pełni owocował. Można sformułować tezę, $\dot{z}$ e w wielu wypadkach to raczej realia epoki historycznej niż wola wychowanków stały u źródeł zaprzepaszczenia znacznej części opisywanego przekazu wychowawczego. Przekaz ten miał bez wątpienia charakter w znacznej mierze archaiczny. Uczniowie $\mathrm{w}$ każdym razie $\mathrm{w}$ większości ciepło edukację domową wspominali i chyba nie tylko dlatego, że lata dziecinne pamięta się w jasnych barwach. Także dlatego, że w opisanym modelu kształcenia i wychowania widzieli wiele wartości. A jeśli uważali, że te wartości się zdezaktualizowały, to często uznawali zarazem, że stało się tak z wielką szkodą dla społeczeństwa i dla przyszłości, która wiele by może skorzystała, gdyby ku swym źródłom jeszcze raz się zwróciła. Zawrócenie czasu nie leżało jednak w mocy nawet najbardziej konsekwentnych w przekazywaniu tradycyjnych wartości młodemu pokoleniu dworów litewskich.

\section{HOME EDUCATION AND UPBRINGING IN POLISH GENTRY FAMILIES IN LITHUANIA AT THE END OF THE XIX CENTURY}

\section{Summary}

The importance of home education and upbringing in Polish gentry houses in Lithuania was the consequence of the strong necessity to protect traditional values and social norms of the landed gentry. These norms and values were threatened due to the processes of social modernization and the Russification policy of the Tsar's government. The author of the article focuses on the contents of the educational process, whose aim was the socialization of the young generation. Pupils were coached to take up their duties as landowners but often also to choose professions which were the traditional haunt of the intelligentsia. The knowledge of etiquette and of the rules of participation in social life was still of great importance. But the knowledge and skills needed to deal with the challenge of modern economy also gradually became the order of the day. Patriotic matters also gained prominence, and the model of "the Polish Mother", a child's first teacher of patriotism was more and more emphasized. The nature of patriotic emotions, fostered by education, was quite complex. It consisted of the family tradition and of national history (treated often as myth and as a basis of national ideology). Teaching of ethical norms was crucial and they were transmitted primarily by the means of religious instruction.

\section{Key words/słowa kluczowe}

education at the end of XIX century / edukacja na przełomie XIX i XX w.; Polish landed gentry / ziemiaństwo polskie; Polish Eastern Borderlands / Kresy 